\section{Money and Monetary Policy: An Essay in Honor of Darryl Francis}

\section{Allan H. Meltzer}

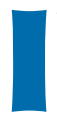
$\mathrm{t}$ is a pleasure to take part in a conference honoring Darryl Francis. Recognition of his courage and leadership is long overdue. Darryl took a leadership role by encouraging the St. Louis monetarist tradition, when it was scorned and derided, by pointing to the need for more restrictive monetary policy in the late 1960s, and in continuing to make the case for lower inflation during his service on the open market committee and as President of the St. Louis Bank.

The 1960s and 1970s were the Keynesian decades in U.S. economic policy. Keynesian policy views were mainstream views in the academic profession. The Council of Economic Advisers then had a more prominent role in economic policy than it has now. The chairmen of the Council in the 1960 s were Walter Heller, Gardner Ackley, and Arthur Okun, all leading Keynesian economists. In the 1970s, the roster includes Paul McCracken, Herbert Stein, and Alan Greenspan, three conservative Keynesians at the time, but Keynesians nonetheless. They were followed by Charles Schultze in the late 1970s.

The primary role of fiscal policy in economic stabilization was a distinguishing characteristic of Keynesian policy. I recall the fervor with which senior professors, young faculty, and bright graduate students sought to overturn Friedman and Meiselman's (1963) demonstration that, except for the Great Depression, monetary velocity was more stable than the Keynesian investment multiplier. Similar fervor greeted Andersen and Jordan's (1968) paper showing that changes in money had stronger and more reliable effects than budget expenditures on changes in nominal gross national product (GNP). As late as Jerome Stein's (1976) conference volume on monetarism, these issues remained highly contentious and hotly debated.

At the height of the controversy in the late 1960s and early 1970s, Darryl Francis was the principal,

Allan H. Meltzer is the Allan H. Meltzer University Professor of Political Economy at Carnegie Mellon University and a visiting scholar at the American Enterprise Institute. and usually the only, spokesman who challenged this orthodoxy at meetings of the Federal Open Market Committee (FOMC). At the time, I was aware of Darryl's role, but I appreciate it even more now that I have access to the FOMC's minutes for that period. I will soon give some examples suggesting that, if Darryl's advice had been taken, we would have avoided the great inflation.

The role of money in monetary policy remains an issue. The Federal Reserve recently gave up the publication of money growth estimates or targets when requirements to publish their estimates expired. The mistake occurred much earlier, when the FOMC stopped using money growth as a measure of the thrust of monetary policy.

Federal Reserve history suggests that neglect of money growth is a major mistake. The Federal Reserve would have avoided mistakes such as the Great Depression and the Great Inflation if it had used money growth as an indicator of the thrust of monetary policy. Below I present some other examples and contrast the role assigned to money growth by the European Central Bank with its neglect by the Federal Reserve.

\section{BEGINNING THE GREAT INFLATION, 1966-69}

From the trough of the 1960-61 recession in February 1961 to the end of 1965, the monetary base accelerated steadily. Annual base growth rose from 2.9 percent to 6 percent. Annual rates of consumer price index (CPI) inflation followed slowly, rising from 0.67 percent in 1961 to 1.9 percent in 1965 . The quarterly average rate, however, reached 3.8 percent (annualized) in fourth quarter 1965 , and the GNP deflator rose more than 4 percent in the first half of 1966.

The Federal Reserve responded to the 4 percent inflation by raising interest rates. Money growth fell. Data available at the time show average M1 growth falling from a maintained rate of 4.4 percent to zero for the second and third quarters of $1966 .{ }^{1}$ Shortterm interest rates rose above 5 percent, the highest levels in the postwar period to that time, indeed the highest levels since the early 1930s.

The economy slowed. Real GNP growth fell from 9 percent in fourth quarter 1965 to less than 2 percent a year later. The inflation rate fell also. Within a few months, the annual rate of inflation was back 1 Contemporary data are from the Federal Reserve Bank of St. Louis
(1972). 
to 2.5 percent. Federal Reserve action reduced the rate of inflation quickly. At the time, the Federal Reserve had considerable credibility. In the 15 years since it had regained independence from the administration, inflation averaged 2 percent and real growth averaged 3.6 percent despite recessions in 1953-54, 1957-58, and 1960-61. The United States had not experienced such good times since the much shorter period of growth and low inflation in the 1920s. William McChesney Martin, Chairman of the Federal Reserve, was not quite the popular figure that Alan Greenspan has become, but he was highly regarded and respected as a defender of price stability.

The good news was about to end in 1966. As we know now, productivity growth reached a peak at about this time and, except for brief periods, inflation rates have not maintained an average rate of 2 percent or less. Indeed, the goal of price stability has been replaced by a current goal of 2 to 3 percent inflation.

Darryl Francis became President at St. Louis in 1966, just as inflation began to rise. Contemporary data show that the CPI inflation rate reached 4.7 percent by late 1967 and more than 6 percent by early 1969. Current data lower these inflation rates to 3.25 percent and 5 percent. The Federal Reserve based decisions and actions on contemporary data, however.

As usual, the Federal Reserve ignored money growth. Facing a recession brought on by the "high" interest rate policy, it reversed its course decisively in 1967. Contemporary data show average M1 growth at 7 percent for the years 1967-68 with inflation at almost 5 percent.

President Johnson, under pressure because his budget deficit financed both an increasingly unpopular war and substantial redistribution, proposed a temporary 10 percent surtax on incomes. This was a fiscal solution to a monetary problem. It could work only if, with a small deficit, the Federal Reserve maintained interest rates and allowed money growth to slow. Keynesian commentary urged the opposite-lower interest rates to offset the tax surcharge. In fact, the monetary base accelerated and, as noted, M1 growth remained about 7 percent.

Excerpts from the FOMC minutes for 1967 and 1968 show that President Francis, usually alone, opposed Federal Reserve policy. His remarks suggest awareness that reducing inflation had a temporary, but real, social cost. He favored fiscal action to reduce the budget deficit but, unlike many of his contemporaries, he did not support the Keynesian approach of easing monetary policy by lowering interest rates and increasing money growth to moderate the contractive effects of higher tax rates. He wanted to reduce money growth, then maintain it at a rate consistent with price stability.

Here are some samples drawn from the FOMC minutes. ${ }^{2}$ In May 1967, with GNP growth down to 1.5 percent, Francis told his FOMC colleagues:

It appeared that the deceleration of economic activity had been halted, and that growth would soon be resumed. The increasing budget deficit of the Federal Government was providing a growing stimulus... Monetary actions had been very expansionary since early this year, and the response in the real sectors of the economy appeared to have been relatively quick. Since monetary and fiscal developments usually had their chief impact after some lag, the basic present problem was not how to achieve adequate total demand but how to avoid excessive demand...[E]xcessive inflation was likely to appear later in the year unless monetary actions were moderated now.

(FOMC, 1967, pp. 567-69)

Francis concluded by urging a money growth rate of 2 to 4 percent instead of the staff's projected rate of 8 to 11 percent.

Chairman Martin "noted that the Committee was not unanimous... with Mr. Francis favoring some firming of money market conditions and the remaining eleven members favoring the maintenance of prevailing conditions" (ibid., p. 573). The Federal Reserve kept the interest rate unchanged. Reported M1 growth reached a 9.7 percent annual rate in that quarter.

In September 1967, a majority of the FOMC favored a modest and cautious increase in interest rates. Francis, joined by two others, dissented. He favored a more aggressive change in the federal funds rate and free reserves. Citing the 9 percent reported growth of M1 and personal income for the most recent six months, he warned the FOMC that current policy "would feed and extend the imminent excessive demand and price inflation" (ibid., p. 973).

Three weeks later, Francis argued that any in-

\footnotetext{
2 The quotations are from the FOMC minutes, which are edited; thus, the statements quoted here may not be exactly the same as the statement made at the time.
} 
crease in interest rates would be temporary, a necessary adjustment to slow inflation and aggregate demand. Congress had not enacted the President's tax increase. He said that the need for monetary restraint was urgent.

Contemporary reports show inflation slowing in the fourth quarter. Several members of the FOMC agreed with Francis that interest rates should be increased to curb the effects of fiscal and monetary stimulus on aggregate demand. They believed, however, the time was not right; the Treasury would soon have to sell bonds.

Francis argued against delay. "[T]his was a pernicious doctrine...[W]hen the Federal budget was excessively stimulative...monetary actions were also excessively stimulative" (ibid., p. 1165).

So it went. Francis encountered one excuse after another. In December 1967, the FOMC discussed selective credit controls as an alternative to higher interest rates and slower money growth. Late in 1967, the Board increased reserve requirement ratios. With interest rates unchanged, however, it supplied the reserves in the open market that it had removed by regulation. Francis made this point at the February 1968 meeting. He urged "an immediate and substantial move toward monetary restraint" (FOMC, 1968, p. 153). Monetary base growth increased to 6 percent or more. In April 1968, Francis argued against those who opposed restraint because of its selective effects on housing. This argument against restraint had political force because higher market interest rates would require an increase in ceiling rates on time deposits under Regulation $\mathrm{Q}$. The thrift industry opposed the increase.

At the March 1968 meeting, Francis lost his vote on the FOMC as part of the annual rotation. He continued to argue forcefully for monetary restraint and to urge the administration to reduce the budget deficit. Throughout 1968, joined by Governor Sherman Maisel, he urged more attention to growth of the monetary aggregates. He complained frequently that the Manager of the System Open Market Account did not respond adequately to the proviso clause in the directive that called for restraint when growth of credit exceeded a specified rate.

The FOMC did not respond to these arguments and did not act. Money growth remained excessive, and inflation continued to rise. Contemporaneous reports show quarterly average CPI inflation above 5 percent in the last half of 1968 .

When, at last, Congress agreed in June 1968 to a tax surcharge, some members of the FOMC wanted to reduce discount rates and ease policy. St. Louis estimated that the full employment budget would shift from a $\$ 14$ billion deficit in the first half of 1968 to a $\$ 10$ billion surplus in the first half of 1969 . In August 1968, Francis told the FOMC that he did not agree with analysts "preoccupied with fear of a coming recession... [and that] in his judgment, the view that the recently adopted fiscal package would, by itself, adequately restrict total demand and cure the inflationary problems was overly optimistic. Monetary actions had continued to be excessively stimulative, negating the desirable anti-inflationary impact of the fiscal package" (ibid., p. 991).

The St. Louis view was that increased money growth would dominate the effect of the tax surcharge. The St. Louis staff forecast increased nominal GNP growth. Contemporary data suggest that growth rates of nominal and real GNP and industrial production slowed in the second half of 1968 . The inflation rate did not fall, however.

In 1969, the St. Louis Federal Reserve Bank proposed increases in the discount rate on six occasions between January and July. The Board initially opposed any increase. At first, St. Louis asked for a 0.5 percent increase to 6 percent. Opponents of the increase gave different reasons. Some Governors wanted to wait until the Treasury completed its financing. Governor Mitchell did not care for 0.5 point increases. He preferred to limit the availability of credit, although he did not say how that could be done without raising interest rates. Governor Brimmer thought that credit expansion resulted from the actions of a few large banks that borrowed Euro-dollars.

By late March, Richmond and Kansas City joined St. Louis in asking for a 0.5 percent increase to 6 percent. Chicago asked for 6.5 percent. Dallas favored an increase also. On April 3, the Board approved the 6 percent rate. Eight weeks later, St. Louis requested an additional 1 percent increase. It renewed the request several times, through late June. By that time, M1 growth had fallen to a 3 percent annual rate. St. Louis, guided by money growth, stopped requesting rate increases. Throughout the summer, Chicago continued to ask for a 7 percent rate. By November, the economy was in recession.

The rest of the story is familiar. By 1971, monetary base growth reached an 8 percent annual rate. The Bretton Woods System ended. Controls reduced the measured rate of inflation, but base money growth increased to 9 percent by 1973. With controls removed, measured CPI inflation reached 7 
percent before the first oil shock and more than 11 percent shortly after.

Darryl Francis had the good sense to rely on the strong research group at St. Louis led by Homer Jones and including Jerry Jordan and Leonall Andersen. Darryl encouraged and supported the group, used their analyses, and articulated a strong position of which he can be proud. His views were unpopular, but with hindsight he knows that he was right.

If the FOMC had acted on his recommendations, the United States and much of the rest of the world would have avoided the worst of the Great Inflation. The Bretton Woods System may not have survived, but it would have lasted longer. The relative price of oil would not have fallen precipitately after the U.S. devaluation, so the oil shock might have been avoided, with positive consequences for productivity growth in the developed countries. With greater certainty, inflation, disinflation, and regulation would not have destroyed the thrift industry. Perhaps, also, there would have been fewer petrodollars to recycle, less bank lending to Latin America, and no debt crisis in the 1980s.

\section{START OF THE GREAT DEPRESSION, ANOTHER EXAMPLE}

Everyone is familiar with the fact that mistaken Federal Reserve policies prolonged and deepened the Great Depression. Attention to money growth would have alerted the Open Market Policy Committee (OMPC) to the severity of deflationary policy. I believe it is now generally accepted that a recession would likely have occurred in 1929, but the Great Depression could have been avoided.

Not only did the Federal Reserve ignore money growth, but its leading official did not know that demand deposits were the major component of the money stock. Darryl was not there to correct the errors, but Irving Fisher was. Fisher told of his visit to Eugene Meyer, Governor of the Federal Reserve Board, in 1931. Fisher told Meyer that demand deposits adjusted had fallen sharply. Meyer asked what they were. According to Fisher, a clerk brought in the ledger. Meyer observed the figures on the page, but he showed little interest and took no expansive action.

The two years before October 1929 are another example of policy error caused by failure to consider money growth as a measure of the thrust of monetary policy. The United States was on the gold standard, but it did not follow gold standard rules. Gold flows were frequently sterilized. Growth of credit and member bank borrowing were the main guides for policy. The Federal Reserve's principal concerns were the rise in stock prices and the use of credit in the stock market.

The rise in stock prices that ended in 1929 is extraordinary by almost any standard except the most recent. From the end of 1924 to September 1929, Standard and Poor's index rose at a 21 percent compound annual rate. The Dow Jones industrial average, at its peak of 381 in September 1929, had doubled in less than two years. The rise was propelled, in part, by rising profits and economic activity. Real GNP and corporate profits rose at annual rates of 4 percent and 12 percent, respectively, with only one mild recession during the nearly five-year period. The increase in market capitalization, relative to nominal GNP, brought the ratio of the two to a level that was not surpassed until 1996.

The rate of rise in corporate profits was much greater than the rate of increase in GNP, but only half the rate of increase in the value of traded stocks (market capitalization). Between 1925 and 1929 the ratio of market capitalization to corporate profits doubled. In absolute value, the ratio rose from 25 in 1925 to 50 at its peak in 1929.

For those brought up on the belief that the 1929 stock market was a wild speculative orgy, the data are surprising. The capitalization ratio rose most rapidly in 1926, with rising profit anticipations. The ratio then remained between 40 and 50 until the market break in 1929. These data suggest that the so-called speculative boom of 1927-29 was driven by rising profits and, most likely, by anticipations of further increases to come. The 17 percent decline in corporate profits in fourth quarter 1929 and the 30 percent decline in first quarter 1930, or anticipation of the decline, must have reversed some of the beliefs built up during the expansion. At the time, many could recall vividly the volatility of the late nineteenth century and the frequent banking panics that Congress intended the Federal Reserve to prevent. Call money rates briefly reached 20 percent in 1929. Rates of 100 percent or more had not occurred in the 15 years of the Federal Reserve's existence. There had been recessions, but the only major deflation, in 1921, was attributed universally to the end of wartime excesses. The belief spread that the Federal Reserve had learned how to maintain prosperity, dampen recessions, and prevent inflation. The return of many countries to the gold standard by 1927 reinforced the view that the world 
economy was on a stable foundation and that inflation and deflation were unlikely to occur.

Irving Fisher commented that the stock market "went up principally because of sound, justified expectations of earnings, and only partly because of unreasoning and unintelligent mania for buying" (Fisher, 1930, p. 53). He credited increased profits to the application of science, technology, and new management methods.

Annual rates of CPI inflation remained negative from July 1926 to May 1929. Restoration of the international gold standard and Federal Reserve actions were a main reason for the sustained, mild deflation of the period. The 12-month moving average of monetary base growth fell below 1 percent in November 1926, turned negative in May 1928, and remained negative through June 1929. In this period of rapid economic growth, monetary policy was deflationary.

The Federal Reserve gave no attention to the monetary base. Its records show, however, that the 1929 increase in output and fall in prices was known at the time. The U.S. economy had a spectacular performance in the first half of the year. Corporate earnings increased about 30 percent in the first nine months. "Large corporate earnings, together with the ability of corporations to float stocks at high [stock] prices... put them in possession of funds with which to complete contemplated expansion programs" ("Review of Business in 1929," Federal Reserve Board; January 15, 1930, preliminary, Box 2461 , p. 4). The only negative influence reported at the time was a decline in residential structures. Industrial and commercial building was at a record level. Exports of manufactured goods increased 50 percent for the year, despite the recession in the last four months (ibid., p. 2).

These data suggest that, as Fisher said, the optimistic projections underlying the rise in stock prices had a factual base. Even after the severe decline at the end of 1929, the Board's staff described the first six months of 1929 as "the continuation of the steady expansion throughout the year 1928" (ibid., p. 5). Industrial production was recorded as 26 percent above the trough of the 1927 recession.

Some questioned or dissented from these optimistic beliefs. Allyn Young, a respected economist of the period, warned about deflation early in 1929 . Unlike many of his contemporaries, who blamed deflation on either a decline in the gold stock or a maldistribution of gold holdings, Young blamed cen- tral bank gold hoarding. He saw that central bank policies forced deflation.

Restoration of the gold standard increased demand for monetary gold stocks. The effect was deflationary for the world economy. The principal creditor countries, France and the United States, increased deflationary pressure by sterilizing gold inflows. France had returned to the gold standard at an exchange rate that undervalued the franc, and Britain at an exchange rate that overvalued the pound. After the French stabilization in 1927, capital returned to France, followed by gold. Much of the flow came from Britain.

The French government disliked the gold exchange standard. It chose to hold gold, not foreign exchange-a policy it repeated in the 1960s. It sold foreign exchange and bought gold to shift the balance in its reserves. These operations reduced French money growth and prevented the rise in prices needed to adjust for the franc's devaluation. The United States had a gold outflow in 1928, an inflow in the first three quarters of 1929. It, too, sterilized most of the gold flows; as noted earlier, the monetary base declined.

U.S. and French policy, therefore, shifted the adjustment burden to the deficit countries. These countries had to deflate or devalue to adjust their real exchange rates. By 1931, Britain, the Scandinavian countries, and many others chose devaluation over continued deflation.

The Federal Reserve ignored the monetary base and money. It focused its attention on the stock market, credit, interest rates, and member bank borrowing. Although aware that the price level had fallen and continued to fall, its concern was inflation, not deflation.

The basis of this concern was the real bills doctrine. Under that doctrine, credit to hold real estate, government debt, and common stocks was "speculative" credit. Such credit permitted wealth owners to hold assets but did not increase the production of goods. According to this doctrine, because credit increased more than output, prices had to rise. Real bills, unlike speculative credit, finance additions to output. Because stock market prices, member bank borrowing, and credit had increased, credit expansion had financed speculation; inflation must result.

The Board's solution was to restrict credit to the stock market by direct pressure and exhortation. The Board did not want to increase the discount rate because that would penalize legitimate borrowers, the suppliers of real bills. Speculative borrowing 
would be encouraged; speculators would continue to borrow because the rate of increase in share prices made them insensitive to small changes in interest rates. That was the reasoning.

Benjamin Strong, Governor of the New York Reserve Bank, was ill in 1928 and died in the autumn. Officials at the New York Bank had been trained by Strong. Strong rejected the notion that the Reserve Banks could control the quality or types of credit that financial institutions granted. He and his followers believed that banks borrowed from the Federal Reserve only in case of need and with reluctance. Increased borrowing at a higher rate would induce banks to contract credit, so they could reduce borrowed reserves. Although increased aggregate borrowing supplied reserves, and this supported more lending, the New York Reserve Bank believed that it would have the opposite effect. In their view, discount rate increases reinforced the effect of reluctance to borrow.

The hot dispute between Washington and New York in 1929 was not about whether monetary contraction was desirable. Although the price level was falling, they agreed about the threat of inflation. They disagreed about how to achieve monetary contraction. If they had paid attention to the monetary base, or followed gold standard rules, they would have allowed money and credit to increase, reducing interest rates and deflation in other countries.

For this policy to succeed fully, France would have had to agree. At the time, they received and sterilized more gold than the United States.

By the spring of 1929 , it was probably too late to stop a worldwide recession, although not too late to stop the severe deflation that followed. The National Bureau of Economic Research marked a cycle peak in April for Germany and July for Britain. March was the peak month for production in Belgium; Canada's peak came in the spring. By fall, financial and business failures had increased in Britain, Germany, and elsewhere (Kindleberger, 1986, pp. 102-04). The Federal Reserve's production index, available at the time, peaked in June. By October, it was 8 percent below the peak. Monthly peaks in the stock markets in the United States, Canada, and France came in September 1929; but markets in Germany, Sweden, and Switzerland reached peaks in 1928; and in Britain the peak came in January 1929 (Kindleberger, 1986, pp. 110 11, based on League of Nations data).

The Great Depression had begun.

\section{THE ECB AND THE FED}

Money has a central role in the framework that the European Central Bank (ECB) uses to link policy actions to their ultimate goal, low inflation. In a recent monograph describing the ECB's strategy and processes, the senior economics staff of the ECB wrote:

The central message from the [monetary] theory, confirmed by the evidence, of a strong link between money and prices, cannot be ignored by a central bank that has price stability as its primary goal. This relationship is a reminder that it is impossible to have high and sustained inflation without monetary accommodation. Since the relationship holds in the long term, there are obvious difficulties to interpret the impact of current monetary developments on inflation in the medium term. Concluding, from the acknowledgement of these difficulties, that money should be neglected altogether is, however, a logical non sequitur. Ignoring money amounts to disregarding an important piece of information. This information is particularly useful to avoid large mistakes in policy, which could arise when the other available indicatorswhose exact relationship with inflation is unknown both in the short and in the long run-fail to signal inflationary risks.

(Angeloni et al., 2000, p. 59)

This statement properly emphasizes two central propositions. First, our knowledge of the short- or medium-term linkage between money and prices is imperfect. U.S. experience in the early 1980s, when money growth gave a series of misleading signals, supports the ECB's interpretation. Second, the long-run relation between money and prices is one of the best-established propositions in economics. Prices may change without money changing, but sustained inflation cannot occur without sustained money growth.

The ECB monograph recognizes that money growth is not a very reliable predictor of shortterm changes in prices or nominal gross domestic product. This should not come as a surprise to Darryl Francis or the St. Louis Federal Reserve Bank. The Andersen-Jordan (1968) equation showed that the response of nominal GNP to money builds up slowly. Evidence suggests that the initial effects of a change 
in the monetary base are absorbed almost entirely by an opposite change in base velocity. There is little or no immediate effect.

One reason for the delayed response is that central banks do not pay attention to short-term changes in money. The most useful hypothesis for the market to use under these circumstances is that short-term changes in money growth are mainly random changes. Base money growth is a noisy series, so it is difficult to extract any useful information from its short-term movements.

The ECB senior staff reaches a similar conclusion. It finds little useful information in short-term changes in money. It adopts a "reference value" of money that the staff believes is "consistent withand will serve to achieve-price stability" (ibid., p. 62). The reference value is the best available forecast of the future growth of money that is consistent with price stability.

The ECB and Federal Reserve procedures differ in several ways. Most striking is the determined attempt by the ECB staff to set out the medium- to long-term framework that guides its actions. It has a long-term objective, price stability, and the outline of a strategy to achieve that objective. The objective is given by law; it is not free to change objectives. Although it takes account of the social cost of achieving price stability, the law does not require it to do so. In principle, it could force the member countries to accept high unemployment to reduce inflation. If it acted that way, however, the law setting its objective would likely change.

The Federal Reserve has a much less clear objective. It claims that price stability is its objective, but there are few times in its almost 90-year history that the nation experienced sustained high employment and low or moderate inflation. Although the last decade is one of the most successful decades in its history, there is as yet no reason to believe that the mixture of wise decisions and good luck will be sustained.

The reason for skepticism is a strong prior belief that is reinforced by my study of Federal Reserve history. The main policy errors of the past were not made by evil men who wanted to create depression or inflation. They were made by officials who believed that money growth was not a useful indicator of future inflation or deflation. Some of the theory or theories on which these officials relied had no place for money. They did not accept, and in many cases rejected explicitly, the proposition that money growth is relevant for inflation or deflation. They paid no attention to money growth.
In the 1920 s and early 1930 s the most popular theory of money was the real bills doctrine. In the 1950 s and 1960s, a simple Keynesian model held the dominant position. The main policy implications of these models highlighted the role of interest rates or borrowing, not money. In the earlier period, the Board dismissed as curious the work and recommendations of Irving Fisher, and in the later period, of Milton Friedman, the St. Louis bank, and other monetarists. Currently, the staff's econometric model has no separate role for money. The quantity of money is determined endogenously. Money growth has no independent role in determining inflation.

This error permeates the staff and, apparently many of the policymakers as well. I believe a main reason for neglecting money now, and for many years, is the Federal Reserve's intense concentration on near-term events. The Federal Reserve does not have a meaningful long-term strategy. At least, it has not made its strategy explicit.

Of course, one can find many words written and spoken about the medium-term, the need to control inflation a year or two ahead, or the small effect of current actions on near-term outcomes. I find it hard to connect these statements to the actions that the Federal Reserve takes, the way it decides to take action, and the messages it sends to the financial markets and others.

The latter message concentrates on short-term changes in principal variables. Many of these data have large reporting errors and are subject to major changes between original announcement and final revision. In an interesting paper, Athanasios Orphanides (2000) showed great differences between the fit of John Taylor's well-known rule when based on initially available data and the later data that appear in the record books. This is one of many examples showing that much of the data used for policy decision is subject to major revisions that can change interpretations.

One cannot rationally object to using new information, if it has content. At issue is the relative weight placed on such data. The Federal Reserve gives lip service to longer-term goals but focuses most attention on short-term changes about which it can do little or nothing. Although it recognizes this point verbally, it has not changed its behavior.

A recent paper by Edward Nelson (2000) revisits the role of money in the United States and the United Kingdom. He finds that, for the period from 1961 to 1999 in the United States, lagged 
growth of real base money balances has a strong, significant effect on a measure of the deviation of output from its long-term trend. The effect of money growth remains powerful when the sample includes only the period from 1982 to 1999 . Nelson includes the real value of the federal funds rate. As he notes, the significant effects of money, given the interest rate, imply that there are effects of money beyond those given by the interest rate. Nelson (2000) estimates a similar equation for the United Kingdom. Again, there are strong, persistent effects of real money growth on the output gap, holding real interest rates constant.

The transmission of monetary policy from initial impulse to final effect involves changes in many relative prices of assets and output. That last statement may seem obvious to many of you, but it is inconsistent with most, if not all, recent work on quarterly dynamic models of monetary policy.

Nelson (2000) introduces base money growth into a small, dynamic optimizing model. He assumes that there are costs of adjusting portfolios. His empirical work shows strong effects of money growth, holding the interest rate constant. These findings supplement and reinforce the conclusion drawn from historical episodes (Meltzer, 2000).

The Federal Reserve's recent decision to ignore money is a mistake. The primary reason for this mistake, and for the difference between the ECB on this issue is, I believe, the excessive emphasis that the Federal Reserve gives to short-term changes.

I have raised the last point several times. Let me develop it further. Every week the government announces new statistics on the economy. Many of these announcements are poor approximations of the data that are later corrected. The daily and weekly commentary speculates on whether the last announcement changes the probability that the Federal Reserve will change interest rates. Markets react. Asset prices move. The next announcement may augment or reverse today's changes.

The weight that each announcement receives depends much less on the quality of the data than on market commentators and participants beliefs about the weight that the Federal Reserve puts on the announcement. The Chairman and other officials give hints and clues about what they watch. These weights shift frequently, and they are not uniform across the members of the FOMC. If there is a hypothesis relating these noisy indicators to long-term objectives, it has never been stated or evaluated.
These criticisms may seem odd, coming as they do in the nineteenth year of a remarkable expansion punctuated by only one mild recession a decade ago. The Federal Reserve deserves and gets much credit for this unique period in U.S. economic history. Its actions reduced inflation in the early 1980s. It responded to the 1990-91 recession without renewing inflation. In 1998-99, it responded to the Asian crisis by financing a domestic boom that permitted the world economy to export to us and, thus, recover. The cost was a rise in U.S. inflation.

These triumphs of judgment over rules and models - and that is what they appear to be - go some way to balance the ledger against the mistakes of the past. A student of monetary history who knows something about probability theory has to recognize that recent successes are, in their way, remarkable. Judgment has been excellent and has produced an excellent record. This general feeling of success is aided by the current popular belief that 2 to 3 percent inflation is acceptable, even desirable.

I will close with three observations. First, the FOMC watches many different indicators that guide changes in the federal funds rate. By chance these may give signals that do not differ very much from the signals given by money growth. Let me offer some examples to suggest that a rule-based strategy relying on money growth would have produced similar results in recent years.

The Shadow Open Market Committee (SOMC) supported the FOMC's gradual policy in 1991-92, when many critics wanted more expansion. The SOMC argued that steady gradual monetary expansion would avoid a surge in aggregate demand and rising inflation and, thus, prolong the expansion. It did not favor more restrictive policy until the fall of 1993, when the monetary base growth rose. The Federal Reserve acted in the winter of 1994, less than six months later.

The SOMC did not join the Phillips curve watchers who warned about the threat of rising inflation in 1996-97. Base money growth remained moderate. The SOMC omitted its September 1997 meeting because it approved of policy at the time. The SOMC did not begin to complain about excessive money growth until March and September 1998. The Federal Reserve was slower to move this time, perhaps because there was no sign of inflation. When the Federal Reserve moved in mid-1999, it moved in a series of decisive steps.

At present, base money growth does not seem excessive. The Federal Reserve has stopped raising 
interest rates, at least for the time being. This is again consistent with growth of the monetary base and other aggregates.

Second, the FOMC in the 1990s differs in an important respect from earlier FOMCs. It gives the markets and the public much more information about its changing policy guides. Markets use this information and, at times, move in advance of Federal Reserve action. This has been true especially since the FOMC surprised the markets in 1994.

Third, and last, a warning from history. The Federal Reserve had a good record in the 1920s. Benjamin Strong, the dominant member of the committee that decided on open market purchases and sales, was highly praised, then and later, for his astute judgments and decisive actions. Irving Fisher wanted Congress to enact a rule mandating price stability. Congress held hearings in 1922, 1926, and 1928. The Federal Reserve opposed the rule, and it was never adopted. Had the rule been followed, it would have avoided the deflation and the worst of the depression. It would have worked when nominal interest rates gave misleading signals.

Fisher talked to Strong about Strong's opposition to his rule. According to Fisher, in a private conversation, Strong replied: "If you will let me alone, I will try to do the best I can, but if you make me do by law what I am trying to do without legislative control, I will be so afraid that I cannot fill the bill that I will not accept the responsibility" (Fisher, 1946, p. 3).

Fisher responded: "I will trust you as long as you live but you will not live forever and when you die I fear your policies will die with you." Strong replied: "I have trained my assistants so that they know these policies and they will be continued" (ibid., p. 3; see also Hetzel, 1985, p. 8).

Strong died soon after. The rest of the story is history. We should not repeat that history even partially.

Both theory and evidence suggest that the interest rate, at times, has been a misleading indicator when money growth gave a correct signal. Darryl Francis's tenure was one of those times. Fortunately, he recognized the error. Unfortunately for us, and much of the rest of the world, his colleagues did not.

\section{REFERENCES}

Andersen, Leonall C. and Jordan, Jerry L. "Monetary and Fiscal Actions: A Test of Their Relative Importance in Economic Stabilization.” Federal Reserve Bank of St. Louis Review, 1968, 50, pp. 11-24.
Angeloni, Ignazio; Gaspar, Vitor; Issing, Otmar and Tristani, Oreste. "Monetary Policy in the Euro Area: Strategy and Decision Making at the European Central Bank." Unpublished manuscript, European Central Bank [Frankfurt], 2000.

Federal Open Market Committee. Minutes. 1967, 1968.

Federal Reserve Bank of St. Louis. Rates of Change in Economic Data for Ten Industrial Countries. May 1972.

Federal Reserve Board. "Review of Business in 1929." Unpublished manuscript, National Archives, Box 2461, 15 January 1930.

Fisher, Irving. The Stock Market Crash and After. New York: Macmillan, 1930.

Fisher, Irving. Letter to Clark Warburton. Unpublished manuscript, 23 July 1946.

Friedman, Milton and Meiselman, David. "Relative Stability of Monetary Velocity and the Investment Multiplier in the United States, 1897-1958," in Commission on Money and Credit, Stabilization Policies. Englewood Cliffs, NJ: Prentice Hall, 1963, pp. 165-268.

Hetzel, Robert. "The Rules Versus Discretion Debate Over Monetary Policy in the 1920s." Federal Reserve Bank of Richmond Economic Review, November/December 1958, 71(6), pp. 3-14.

Kindleberger, Charles P. The World in Depression, 1929 1939 [revised]. Berkeley: University of California Press, 1986.

Meltzer, Allan H. "The Transmission Process," in The Monetary Transmission Process: Recent Developments and Lessons for Europe. Frankfurt: Deutsche Bundesbank, 2000.

Nelson, Edward. "Direct Effects of Base Money on Aggregate Demand: Theory and Evidence." Unpublished manuscript, Bank of England, May 2000.

Orphanides, Athanasios. "The Quest for Prosperity Without Inflation." Unpublished manuscript, Board of Governors, 2000 .

Stein, Jerome. Monetarism. Amsterdam: North Holland, 1976. 
REVIE W

32 JULY/AUgUST 2001 